\title{
Activated defense systems in marine macroalgae: evidence for an ecological role for DMSP cleavage
}

\author{
Kathryn L. Van Alstyne ${ }^{1, *}$, Gordon V. Wolfe ${ }^{2}$, Tess L. Freidenburg ${ }^{3}$, \\ Anna Neill' ${ }^{1}$, Corrine Hicken ${ }^{1}$ \\ ${ }^{1}$ Shannon Point Marine Center, 1900 Shannon Point Road, Anacortes, Washington 98221, USA \\ ${ }^{2}$ Department of Biological Sciences, California State University, Chico, California 95929-0515, USA \\ ${ }^{3}$ Department of Zoology, Oregon State University, Corvallis, Oregon 97331, USA
}

\begin{abstract}
Activated defenses against herbivores and predators are defenses whereby a precursor compound is stored in an inactive or mildly active form. Upon damage to the prey, the precursor is enzymatically converted to a more potent toxin or feeding deterrent. In marine systems, activated defenses are only known to exist in a few species of tropical macroalgae. In this study, we examined an activated defense system in temperate marine macroalgae in which the osmolyte dimethylsulfoniopropionate (DMSP) is converted to acrylic acid or acrylate, depending upon the $\mathrm{pH}$, and dimethyl sulfide (DMS) by the enzyme DMSP lyase upon damage to the alga. We surveyed 39 species of red, green, and brown algae from the Washington and Oregon coasts, and found high concentrations of DMSP in the chlorophytes Acrosiphonia coalita, Codium fragile, Enteromorpha intestinalis, E. linza, Ulva californica, U. fenestrata, and U. taeniata, and in the rhodophyte Polysiphonia hendryi. Concentrations of DMSP ranged from $0.04 \%$ of the alga's fresh mass (FM) to $1.8 \%$ FM. We found significant DMSP lyase activity in 1 green alga, $U$. fenestrata, and 1 red alga, $P$. hendryi, with DMSP cleav-

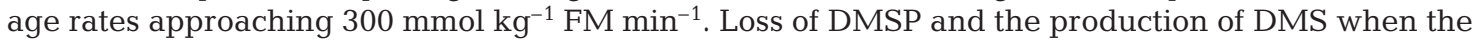
tissues of $U$. californica and $P$. hendryi were crushed suggested that physical damage results in DMSP cleavage. In laboratory feeding preference experiments, acrylic acid deterred feeding by the sea urchin Strongylocentrotus droebachiensis at concentrations of 0.1 to $2 \%$ FM and by $S$. purpuratus at 0.25 to $2 \%$ FM, while the precursor DMSP functioned as a feeding attractant to both sea urchins. In contrast, feeding by the isopod Idotea wosnesenskii was not deterred by acrylic acid even at concentrations as high as $8 \%$ FM. Our data suggest that DMSP may function as a precursor in an activated defense system in diverse species of temperate macroalgae and may possibly contribute to the widespread success of the Ulvophyceae. This chemical system is also found in unicellular phytoplankton, and presents an opportunity to compare and contrast the ecological role of chemical defense among micro- and macroorganisms.
\end{abstract}

KEY WORDS: Acrylic acid · Activated defenses · DMSP $\cdot$ Herbivory $\cdot$ Macroalgae

Resale or republication not permitted without written consent of the publisher

\section{INTRODUCTION}

Marine macroalgae produce a variety of secondary metabolites, including many that function as herbivore deterrents (Hay \& Fenical 1988, Van Alstyne \& Paul 1989, Hay \& Steinberg 1992, Paul 1992, Targett \& Arnold 1998). Secondary metabolite levels in macroal-

\footnotetext{
*E-mail: kathyva@Cc.wwu.edu
}

gae can be influenced by or correlated with a number of environmental factors including light intensity (Cronin \& Hay 1996b,c, Pavia et al. 1997), nutrient levels (Ilvessalo \& Tuomi 1989, Yates \& Peckol 1993, Arnold et al. 1995, Cronin \& Hay 1996a, Peckol et al. 1996), desiccation (Renaud et al. 1990), and salinity (Pedersen 1984). In some species, biological interactions, such as grazing, affect the types and levels of defenses. Several species of marine macroalgae produce induced defenses in which defense production increases after 
algae are damaged by herbivores (Van Alstyne 1988, Yates \& Peckol 1993, Cronin \& Hay 1996b, Peckol et al. 1996, Hammerstrom et al. 1998). The induction of defenses occurs over a period of days (Hammerstrom et al. 1998) to weeks (Van Alstyne 1988) and may be dependent upon nutrient levels (Yates \& Peckol 1993, Peckol et al. 1996).

An alternative mechanism by which grazers influence the potency of defenses in their prey is the production of activated defenses. Activated defenses are compounds that are stored in plants in a non-toxic or mildly toxic form. Upon damage to the tissue, stored compounds are converted to more deterrent compounds. It is suspected that damage activates an enzyme or enzymes that convert the less toxic compound (the substrate or precursor) to the more deterrent compound (the product) and other by-products.

Activated defenses have been reported from a variety of terrestrial plants. For example, many crucifers produce glucosinolates that are converted to mustard oils in a series of reactions involving the enzyme myrosinase (Chew 1988, Louda \& Mole 1991). Mustard oils are toxic towards many herbivorous mammals and generalist insect grazers. Native plants producing glucosinolates are typically fast-growing, ephemeral species (Louda \& Mole 1991). Similarly, cyanogenic glycosides are non-toxic compounds found in almost all the major groups of vascular plants (Conn 1979, 1981, Seigler 1991). When plant tissues are crushed, cyanogenic glycosides are enzymatically hydrolyzed, usually by $\beta$ glycosidases or hydroxynitrile lyases, and hydrogen cyanide (HCN) is released (Seigler 1991). HCN and the other products of this reaction, sugars, aldehydes and ketones, may be toxic to non-adapted herbivores, although many animals are capable of detoxifying limited quantities of HCN (Conn 1979, Seigler 1991). Similar conversions of compounds have also been reported that involve phenolic glycosides in terrestrial vascular plants (Clausen et al. 1989), sesquiterpenes in mushrooms (Sterner 1985, Sterner et al. 1985), and glucosinolates in aquatic vascular plants (Newman et al. 1992). Activated defenses have been described in tropical siphonous green algae (Paul \& Van Alstyne 1992). However, there are no published reports of activated defenses in temperate marine macroalgae.
This study examines the role of dimethylsulfoniopropionate (DMSP) in an activated defense system in northern Pacific marine macroalgae. DMSP, a tertiary sulfonium derivative of methionine, is found in many species of green and red macroalgae in habitats ranging from polar (Karsten et al. 1990) to temperate (White 1982, Reed 1983a) to tropical (Bischoff et al. 1994, Dacey et al. 1994). It is also abundant in phytoplankton and some halotolerant vascular plants (Dacey \& Wakeham 1986, Keller et al. 1989, Rhodes \& Hanson 1993, Otte \& Morris 1994). DMSP is a compatible solute (Reed 1983a, Kirst 1989, Kirst et al. 1991, Karsten et al. 1992) and may also play a role in cryoprotection in polar algae (Kirst et al. 1991, Karsten et al. 1992). Although it functions in osmoregulation, DMSP concentrations do not respond to short-term (hourly) salinity changes (Reed 1983a,b, Dickson \& Kirst 1986, Edwards et al. 1987, 1988), but only to longer-term adaptations (Edwards et al. 1988).

DMSP was first identified by Challenger \& Simpson (1948) as a substrate for transmethylation and also as the precursor for dimethyl sulfide (DMS) production, as noted by Haas (1935) in Polysiphonia fastigiata. The cleavage pathway producing DMS and acrylic acid (Fig. 1) was also detected in Enteromorpha intestinalis by Bywood \& Challenger (1953). Cantoni \& Anderson (1956) showed that the reaction was catalyzed by the enzyme DMSP lyase. The DMS produced by this reaction is important to the global sulfur cycle (e.g., Lovelock et al. 1972, Andreae \& Raemdonck 1983, Liss et al. 1994, Groene 1995, Malin \& Kirst 1997) and possibly to climate (Bates et al. 1987, Charlson et al. 1987). Although the cleavage reaction has been the subject of intense study, its biological function is still poorly understood.

In oceanic systems, DMS production is often associated with grazing on phytoplankton containing DMSP (Dacey \& Wakeham 1986, Daly \& DiTullio 1993). Recently, the DMSP-cleavage reaction was proposed as an activated defense system in microalgae (Wolfe \& Steinke 1996, Wolfe et al. 1997), producing concentrated acrylate inside protozoan food vacuoles. We hypothesized that DMSP may also function as part of an herbivore-activated defense system in marine macroalgae. To test this hypothesis, we first examined

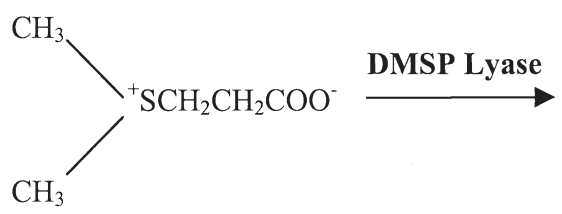

DMSP

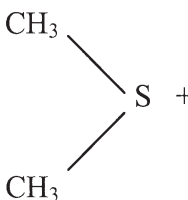

DMS<smiles>CCC(=O)[O-]</smiles>

Acrylate

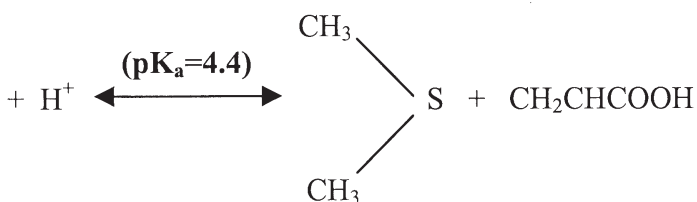

DMS
Acrylic Acid

Fig. 1. Conversion of DMSP by DMSP lyase to DMS and acrylate or acrylic acid 
local northeastern Pacific macroalgae to determine whether they produced DMSP and DMSP lyase. We then conducted experiments to determine if acrylic acid and DMSP deter feeding by local generalist grazers. The results of our study provide strong evidence that DMSP can function in an activated defense system in some macroalgal species.

\section{MATERIALS AND METHODS}

Collection sites and study organisms. Purple sea urchins Strongylocentrotus purpuratus were collected from low- to mid-intertidal pools at Boiler Bay, Oregon, USA $\left(44^{\circ} 40^{\prime} \mathrm{N}, 124^{\circ} 03^{\prime} \mathrm{W}\right)$. All sea urchins were kept in flow-through seawater tables at the Hatfield Marine Science Center (HMSC) in Newport, Oregon, and fed a mixture of red, green and brown macroalgae. Green sea urchins $S$. droebachiensis were collected with SCUBA from $\sim 5 \mathrm{~m}$ depth from Burrows Channel at the north end of Fidalgo Island, Washington, USA $\left(48^{\circ} 29^{\prime} \mathrm{N}, 122^{\circ} 41^{\prime} \mathrm{W}\right)$. Isopods Idotea wosnesenskii were collected from the low intertidal zone at the Fort Ebey boat launch on Whidbey Island, Washington $\left(48^{\circ} 15^{\prime} \mathrm{N}, 122^{\circ} 45^{\prime} \mathrm{W}\right)$. S. droebachiensis and I. wosnesenskii were maintained in flow-through seawater tables at the Shannon Point Marine Center and were fed a mixed-species diet of macroalgae. Macroalgae for DMSP and DMSP lyase analysis were collected from a number of intertidal sites including Boiler Bay, Oregon, the beach in front of the Shannon Point Marine Center in Anacortes, Washington $\left(48^{\circ} 31^{\prime} \mathrm{N}\right.$, $\left.122^{\circ} 41^{\prime} \mathrm{W}\right)$, the Friday Harbor Laboratories $\left(48^{\circ} 33^{\prime} \mathrm{N}\right.$, $\left.123^{\circ} 01^{\prime} \mathrm{W}\right)$ and Jackell's Lagoon $\left(48^{\circ} 31^{\prime} \mathrm{N}, 123^{\circ} 01^{\prime} \mathrm{W}\right)$ on San Juan Island, Washington, and from Allan Island Washington $\left(48^{\circ} 28^{\prime} \mathrm{N}, 122^{\circ} 42^{\prime} \mathrm{W}\right)$.

Analysis of DMSP concentrations and DMSP lyase activity. DMSP was analyzed as DMS following alkaline cleavage with methods similar to those described in Wolfe et al. (1994). Freshly collected algal samples were weighed and placed in $5 \mathrm{ml}$ of $10 \mathrm{~N} \mathrm{NaOH}$ in $100 \mathrm{ml}$ serum vials and sealed with Teflon-coated septa. Bottles were incubated in the dark for a minimum of $12 \mathrm{~h}$ to allow complete conversion to DMS, and shaken to hasten equilibration with headspace. Ten to $100 \mu \mathrm{l}$ of DMS was sampled from the headspace by gas-tight syringe and injected to a gas chromatograph equipped with a Chromosil 330 column and flame photometric detector. DMSP standard additions to equal volumes of $\mathrm{NaOH}$ were used for calibration.

We measured DMSP lyase concentrations in 2 of the macroalgal species that contained measurable amounts of DMSP, Ulva fenestrata (Chlorophyta) and Polysiphonia hendryi (Rhodophyta). Algae were collected and epiphytic algae were removed from their surfaces. They were then rinsed briefly in ice-cold deionized water and blotted dry. Because DMSP lyase activity may be $\mathrm{pH}$-sensitive, algal tissues (0.5 to $2.0 \mathrm{~g}$ ) were ground using a chilled mortar and pestle in each of 3 buffers of differing $\mathrm{pH}$ : (1) $100 \mathrm{mM}$ sodium citrate, $1 \mathrm{M} \mathrm{NaCl}, 10 \%$ (v/v) glycerol, and $0.5 \%$ (v/v) polyoxyethylenesorbitan (Tween-80), pH 5.2; (2) $100 \mathrm{mM}$ 2-[N-morpholino]ethanesulfonic acid (MES), $1 \mathrm{M} \mathrm{NaCl}$, $10 \%$ (v/v) glycerol, and $0.5 \%$ (v/v) Tween-80, pH 6.2; and (3) $100 \mathrm{mM}$ 2-[N-morpholino]ethanesulfonic acid (MES), $1 \mathrm{M} \mathrm{NaCl}, 10 \%$ (v/v) glycerol, and $0.5 \%$ (v/v) Tween-80, pH 7.2.

The homogenate was transferred to a microcentrifuge tube and incubated on ice with occasional stirring for $30 \mathrm{~min}$, then spun in a centrifuge at $4500 \mathrm{rpm}$ $(3000 \times g)$ for $5 \mathrm{~min}$. The pellet was collected and resuspended in $1 \mathrm{ml}$ of buffer then centrifuged again. The supernatants from both centrifugations were pooled and diluted 1:100 with deionized water. Extract $(270 \mu \mathrm{l})$ and $10 \mu \mathrm{l}$ of $30 \mathrm{mM}$ dithiothreitol (DTT) were added to $2 \mathrm{ml}$ gas-tight vials and equilibrated to room temperature. DMS concentrations were determined from headspace samples $(10 \mu \mathrm{l})$ collected from the vials and used to establish a baseline of DMS production. Once the baseline was established, the reaction was initiated by adding DMSP-Cl (University of Gronigen Chemical Laboratory, The Netherlands) to a final concentration of $10 \mathrm{mM}$. DMS concentrations in the headspace were quantified over 20 to 50 min after the addition of DMSP.

Feeding bioassays with DMSP and acrylic acid. The effectiveness of acrylic acid and DMSP as feeding deterrents and attractants was tested with 2-choice laboratory bioassays in which compounds were incorporated into diets and feeding rates on those diets were compared. Diets for assays involving Strongylocentrotus purpuratus were made by homogenizing $30 \mathrm{~g}$ of sushi nori (Porphyra sp.) in a blender with $600 \mathrm{ml}$ of tap water. The solid materials were filtered out through several layers of cheesecloth and the remaining water extract was stored in darkness at $4{ }^{\circ} \mathrm{C}$. An anchovy homogenate was made by grinding $57 \mathrm{~g}$ of anchovies packaged in olive oil and $200 \mathrm{ml}$ of tap water in a blender. The homogenate was also stored at $4^{\circ} \mathrm{C}$ in darkness prior to use. Diets were made by combining $4.5 \mathrm{~g}$ of agar with $75 \mathrm{ml}$ of the nori extract, heating the mixture in a microwave at highest power for $60 \mathrm{~s}$, and then adding $3 \mathrm{ml}$ of anchovy extract. DMSP-Cl (University of Gronigen Chemical Laboratory, The Netherlands) or acrylic acid (Sigma) were added to the diet after it had cooled but before it gelled to avoid thermal decomposition. The diet was then poured into shallow trays and cooled. After the diets had gelled, $\sim 3 \mathrm{~cm}$ diameter pieces were cut and weighed. Distilled water without acrylic acid was added to control diets. 
In feeding experiments at HMSC, urchins Strongylocentrotus purpuratus were offered 2 pieces of diet in $20 \mathrm{~cm}$ diameter round plastic containers. To start the experiments, the diets were placed in the center of the containers and the urchins were placed on top of the diets so they had equal access to each piece of food. The containers were filled almost to the top with seawater and were placed in a seawater table with seawater flowing around, but not into the containers, to cool the water in the containers. Urchins were allowed to feed on the diets until about half of the food in the containers had been consumed. Replicates were discarded if the urchins did not consume at least half the food in the containers in a $6 \mathrm{~h}$ period. Preliminary experiments showed that in the absence of herbivores mass loss of the diets over a $6 \mathrm{~h}$ period was generally less than $2 \%$ and did not differ in control diets versus diets containing acrylic acid; therefore, control arenas for autogenic losses were not used in these experiments. Urchins were starved for $2 \mathrm{wk}$ before being used in feeding experiments in order to ensure they would eat the diets rapidly. Some herbivores have been shown to be less selective when starved (Cronin \& Hay 1996c). If this is the case for the herbivores we used, then these assays should be conservative in determining the effectiveness of acrylic acid and DMSP. After the urchins were removed from the containers, the remaining pieces of diet were blotted dry and weighed. The change in mass of the treated food in each replicate was subtracted from the change in mass of the control food and the differences were compared to zero $(\alpha=0.05)$ with a 1-sample Student's $t$-test as described in Peterson \& Renaud (1989).

Feeding experiments with Strongylocentrotus droebachiensis were conducted in a similar manner at the Shannon Point Marine Center (SPMC) in Anacortes, Washington. The diets were prepared as described above except that they contained $40 \mathrm{~g}$ of Laminaria saccharina homogenate (300 g L. saccharina homogenized with $300 \mathrm{~g}$ water), $3.5 \mathrm{~g}$ agar, $50 \mathrm{ml}$ deionized water, and $3 \mathrm{ml}$ of anchovy homogenate. The heated mixture was poured onto a $25 \times 25 \mathrm{~cm}$ glass plate with $4 \mathrm{~mm}$ plastic spacers at each corner. A second glass plate was placed on the spacers and served to flatten the agar mixture to a uniform width. Three grams of filtered beach sand was spread in a thin layer on the bottom plate before pouring the agar; this acted as a weight to keep the food from floating.

Diets for experiments involving isopods Idotea wosnesenskii were made as described for Strongylocentrotus purpuratus diets, except that the diet was made with $2.5 \mathrm{~g}$ agar, $100 \mathrm{ml}$ water, and $2 \mathrm{~g}$ ground, ovendried $\left(60^{\circ} \mathrm{C}\right.$ for $\left.48 \mathrm{~h}\right)$ Ulva fenestrata. Two-choice experiments were conducted in $20 \mathrm{~cm}$ diameter plastic containers to which $1 \mathrm{~mm}$ mesh fiberglass screens were added to allow water flow through the containers. Isopods were allowed to feed until approximately half the food in a container had been removed. Arenas in which isopods did not consume at least half the food in $24 \mathrm{~h}$ were not included in the analyses. Statistical analyses were conducted as described above.

\section{RESULTS}

\section{DMSP concentrations}

Detectable concentrations of DMSP were found in 7 of 8 green algal species examined: Acrosiphonia coalita, Codium fragile, Enteromorpha intestinalis, E. linza, Ulva californica, U. fenestrata, and U. taeniata (Table 1). Concentrations of DMSP in chlorophytes ranged from $0.04 \% \mathrm{FM}$ in C. fragile to $1.68 \% \mathrm{FM}$ in E. linza. Only 1 species of red algae, Polysiphonia hendryi, had detectable concentrations of DMSP (Table 1). None of the brown algae examined had detectable concentrations of DMSP.

Several of the algae were sampled across more than one site and on more than one date. Concentrations of DMSP in Ulva californica and Polysiphonia hendryi were similar ( $p>0.05$, Student's $t$-test) in tissues collected in January and February from Boiler Bay, Oregon; however, concentrations differed significantly between samples collected in winter at Boiler Bay and summer at Anacortes, Washington (Table 1). Concentrations of DMSP in $P$. hendryi were also significantly higher in the summer San Juan Island collection than the winter Boiler Bay collection (Table 1; 1 -way ANOVA: $F=6.28, \mathrm{p}=0.009$, Tukey's test, $\mathrm{p}<$ $0.05)$, indicating that among-site or seasonal variation in DMSP levels was occurring. Concentrations of DMSP in Ulva taeniata were significantly higher in algae collected from Anacortes than from San Juan Island in the summer of 1997 (Table 1; 1-way ANOVA: $F=7.57, \mathrm{p}=0.031$, Tukey's test, $\mathrm{p}<0.05$ ). Concentrations were significantly higher in the winter Boiler Bay collection of Enteromorpha intestinalis than in the summer Anacortes collection (Table 1; Student's $t$-test: $t=5.56 \mathrm{p}=0.011$ ). DMSP concentrations in Codium fragile did not differ significantly between the winter Boiler Bay collections and the summer Anacortes collections (Table 1; Student's $t$ test, $t=-1.91, \mathrm{p}=0.31$ ).

\section{DMSP lyase activity}

We found significant DMSP lyase activity in both Ulva fenestrata and Polysiphonia hendryi (Fig. 2). 
Table 1. Mean DMSP $( \pm 1$ SD) concentrations in marine macroalgae from Washington and Oregon, USA, sites. nd: DMSP was not detectable. FM: fresh mass

\begin{tabular}{|c|c|c|c|c|}
\hline Species & Site & Date & $\begin{array}{l}\text { [DMSP] } \\
\text { (\% FM) }\end{array}$ & $\mathrm{n}$ \\
\hline \multicolumn{5}{|l|}{ Phylum (division) Chlorophyta } \\
\hline Acrosiphonia coalita & Anacortes, WA & Jul 98 & $0.08 \pm 0.02$ & 2 \\
\hline Cladophora sp. & Boiler Bay, OR & Feb 97 & nd & 3 \\
\hline \multirow[t]{2}{*}{ Codium fragile } & Boiler Bay, OR & Feb 97 & $0.04 \pm 0.02$ & 3 \\
\hline & Anacortes, WA & Jul 98 & $0.20 \pm 0.11$ & 2 \\
\hline \multirow[t]{2}{*}{ Enteromorpha intestinalis } & Boiler Bay, OR & Feb 97 & $0.33 \pm 0.04$ & 3 \\
\hline & San Juan Island, WA & Jul 98 & $0.18 \pm 0.03$ & 3 \\
\hline Enteromorpha linza & Anacortes, WA & Jul 98 & $1.68 \pm 0.00$ & 1 \\
\hline \multirow[t]{3}{*}{ Ulva californica } & Boiler Bay, OR & Jan 97 & $1.04 \pm 0.14$ & 3 \\
\hline & Boiler Bay, OR & Feb 97 & $0.84 \pm 0.10$ & 3 \\
\hline & Anacortes, WA & Jul 98 & $1.58 \pm 0.31$ & 2 \\
\hline Ulva fenestrata & San Juan Island, WA & Jul 98 & $0.99 \pm 0.39$ & 3 \\
\hline \multirow[t]{3}{*}{ Ulva taeniata } & San Juan Island, WA & Jul 98 & $0.49 \pm 0.22$ & 3 \\
\hline & Anacortes, WA & Jul 97 & $1.08 \pm 0.21$ & 3 \\
\hline & Anacortes, WA & Jul 98 & $0.90 \pm 0.08$ & 2 \\
\hline \multicolumn{5}{|l|}{ Phylum Rhodophyta } \\
\hline Calliarthron tuberculosum & Boiler Bay, OR & Feb 97 & nd & 3 \\
\hline Callithamnion sp. & San Juan Island, WA & Jul 97 & nd & 3 \\
\hline Ceramium sp. & San Juan Island, WA & Jul 97 & nd & 3 \\
\hline Colpomenia bullosa & Anacortes, WA & Jul 98 & nd & 2 \\
\hline Corallina officianalis & Boiler Bay, OR & Feb 97 & nd & 3 \\
\hline Corallina vancouveriensis & Boiler Bay, OR & Feb 97 & nd & 3 \\
\hline Endocladia muricata & Boiler Bay, OR & Jan 97, Feb 97 & nd & 3,3 \\
\hline Mastocarpus papillatus & Boiler Bay, OR & Jan 97, Feb 97 & nd & 3,3 \\
\hline Mazzeaella cornucopiae & Boiler Bay, OR & Feb 97 & nd & 3 \\
\hline Membranoptera multiramosa & Boiler Bay, OR & Feb 97 & nd & 3 \\
\hline Microcladia borealis & San Juan Island, WA & Jul 97 & nd & 3 \\
\hline Neorhodomela larix & Boiler Bay, OR & Feb 97 & nd & 3 \\
\hline \multirow{2}{*}{ Odonthalia flocossa } & Boiler Bay, OR & Jan 97, Feb 97 & nd & 3,6 \\
\hline & San Juan Island, WA & Jul 97 & nd & 3 \\
\hline 'Petrocelis' & Anacortes, WA & Jul 99 & nd & 2 \\
\hline Plocamium cartilaginum & Boiler Bay, OR & Feb 97 & nd & 1 \\
\hline Plocamium violaceum & Boiler Bay, OR & Feb 97 & nd & 3 \\
\hline \multirow[t]{3}{*}{ Polysiphonia hendryi } & Boiler Bay, OR & Feb 97 & $0.10 \pm 0.08$ & 3 \\
\hline & San Juan Island, WA & Jul 97 & $0.40 \pm 0.14$ & 15 \\
\hline & Anacortes, WA & Jul 98 & $0.30 \pm 0.10$ & 2 \\
\hline Porphyra sp. 1 & Boiler Bay, OR & Feb 97 & nd & 3 \\
\hline Porphyra sp. 2 & Anacortes, WA & Jul 98 & nd & 2 \\
\hline Porphyra sp. 3 & Boiler Bay, OR & Feb 97 & nd & 3 \\
\hline Prionitis lanceolata & Boiler Bay, OR & Feb 97 & nd & 3 \\
\hline \multirow[t]{2}{*}{ Ptilota filicina } & Boiler Bay, OR & Jan 97 & nd & 3 \\
\hline & San Juan Island, WA & Jul 97 & nd & 3 \\
\hline \multicolumn{5}{|l|}{ Phylum Phaeophyta } \\
\hline Egregia menziesii & Boiler Bay, OR & Feb 97 & nd & 3 \\
\hline Fucus gardneri & Boiler Bay, OR & Feb 97 & nd & 3 \\
\hline Fucus spiralis & Boiler Bay, OR & Feb 97 & nd & 3 \\
\hline Leathesia difformis & Anacortes, WA & Jul 98 & nd & 2 \\
\hline Pelvetiopsis limitata & Boiler Bay, OR & Feb 97 & nd & 3 \\
\hline Phaeostrophion irregulare & Boiler Bay, OR & Feb 97 & nd & 3 \\
\hline Scytosiphon lomentaria & Boiler Bay, OR & Feb 97 & nd & 3 \\
\hline
\end{tabular}



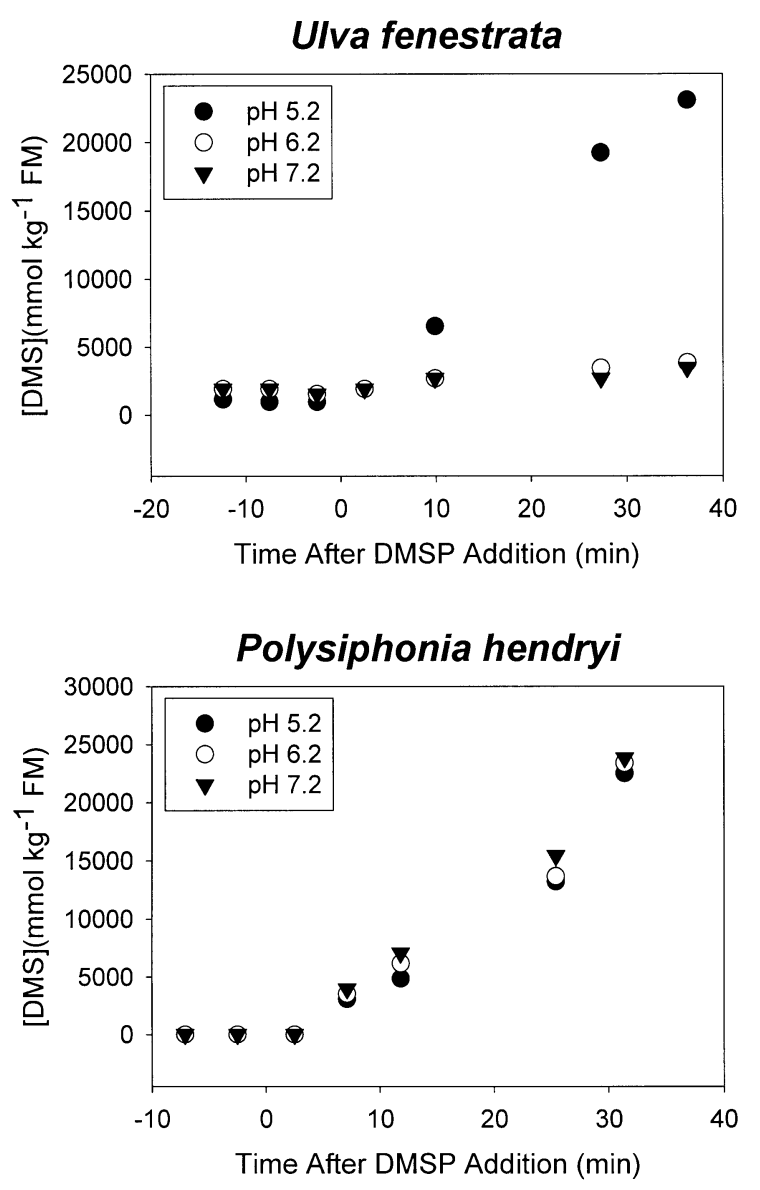

Fig. 2. Ulva fenestrata (Chlorophyta) and Polysiphonia hendryi (Phodophyta). DMSP lyase activity at $3 \mathrm{pH}$ levels. Measurements at times less than zero were taken before addition of DMSP to the algal extract. FM: fresh mass

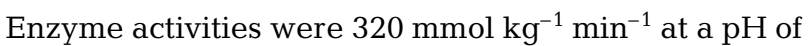
5.2 in $U$. fenestrata and 260 to $270 \mathrm{mmol} \mathrm{kg}^{-1} \mathrm{~min}^{-1}$ in $P$. hendryi. DMSP lyase in U. fenestrata was sensitive to the $\mathrm{pH}$ of the buffer used, whereas DMSP lyase in $P$. hendryi was not, within the range of buffers used in the analyses. High DMSP lyase activity was seen at pH 5.2, 6.2 , and 7.2 in $P$. hendryi. In $U$. fenestrata, enzyme activity was highest at a $\mathrm{pH}$ of 5.2 ; little activity was seen at $\mathrm{pH} 6.2$ or 7.2 .

Although we did not quantify cleavage of DMSP following tissue damage, we compared concentrations of DMSP in whole tissues to tissues that were crushed using a mortar and pestle. Grinding tissues of both Ulva californica and Polysiphonia hendryi resulted in a significant decrease in DMSP levels (Table 2; 2-way ANOVA: grinding effect, $F=7.86, \mathrm{p}=0.023$, species effect, $F=203.27, \mathrm{p}<0.001$, grinding $\times$ species effect, $F=1.52, \mathrm{p}=0.253$ ), and $P$. hendryi gave off a strong odor of DMS when crushed.
Table 2. Ulva californica and Polysiphonia hendryi. Mean ( $\pm 1 \mathrm{SE}$ ) DMSP concentrations (\% fresh mass, FM) in crushed and uncrushed tissues

\begin{tabular}{|lcc|}
\hline Species & $\begin{array}{c}\text { Uncrushed tissues } \\
\text { [DMSP] }(\% \text { FM) }\end{array}$ & $\begin{array}{c}\text { Crushed tissues } \\
\text { [DMSP] (\% FM) }\end{array}$ \\
\hline Polysiphonia hendryi & $\begin{array}{c}0.10 \pm 0.05 \\
(\mathrm{n}=3)\end{array}$ & $\begin{array}{c}0.03 \pm 0.01 \\
(\mathrm{n}=3)\end{array}$ \\
Ulva californica & $\begin{array}{c}0.84 \pm 0.05 \\
(\mathrm{n}=3)\end{array}$ & $\begin{array}{c}0.65 \pm 0.06 \\
(\mathrm{n}=3)\end{array}$ \\
& & \\
\hline
\end{tabular}

\section{Bioassays with herbivores}

The addition of acrylic acid to diets significantly reduced feeding by Strongylocentrotus purpuratus at concentrations from 2 to $0.25 \%$ FM, but not at $0.1 \%$ FM (Fig. 3, 1-sample $t$-test, $\mathrm{p}<0.05$ ). In contrast, DMSP acted as a significant feeding attractant at concentrations from 4 to $0.5 \%$ FM, but not at $0.25 \%$ FW (Fig. 3, 1-sample $t$-test, $\mathrm{p}<0.05$ ). When urchins were offered choices of diets containing DMSP and diets containing acrylic acid at equimolar concentrations, they significantly preferred the DMSP-containing diet (Fig. 3, 1-sample $t$-test, $\mathrm{p}<0.05$ ), except at the lowest concentration $(0.2 \%$ FM DMSP vs $0.1 \%$ acrylic acid), in which there was no significant preference (Fig. 3, 1 -sample $t$-test, $\mathrm{p}>0.05$ ).

Assays with green sea urchins Strongylocentrotus droebachiensis produced similar results. The addition of acrylic acid to the diets reduced feeding at all concentrations tested from 0.1 to $2 \%$ FM (Fig. 4, 1-sample $t$-test, $\mathrm{p}<0.05)$. The addition of DMSP acted as a feeding attractant at concentrations of 0.5 to $2 \%$ FM (Fig. 4, 1-sample $t$-test, $\mathrm{p}<0.05$ ), but was not significantly attractant at concentrations of 0.2 or $4 \%$ FM (Fig. 4, 1-sample $t$-test, $\mathrm{p}>0.05$ ). Diets containing DMSP were preferred over diets containing equimolar amounts of acrylic acid at all concentrations tested (Fig. 4, 1-sample $t$-test, $\mathrm{p}<0.05$ ).

Feeding by the isopods Idotea wosnesenskii was not deterred by the addition of acrylic acid to the diets (Fig. 5). Acrylic acid was a significant feeding attractant to isopods at concentrations of 0.1 and $1 \%$ FM (1-sample $t$-test, $\mathrm{p}<0.05)$. At all other concentrations, up to $8 \% \mathrm{FM}$, there were no significant differences in feeding rates on control diets versus diets containing acrylic acid (1-sample $t$-test, $\mathrm{p}>0.05)$.

\section{DISCUSSION}

\section{Evidence for activated defense}

The occurrence and concentrations of DMSP we observed are similar to previous observations of temper- 


\section{Strongylocentrotus purpuratus}
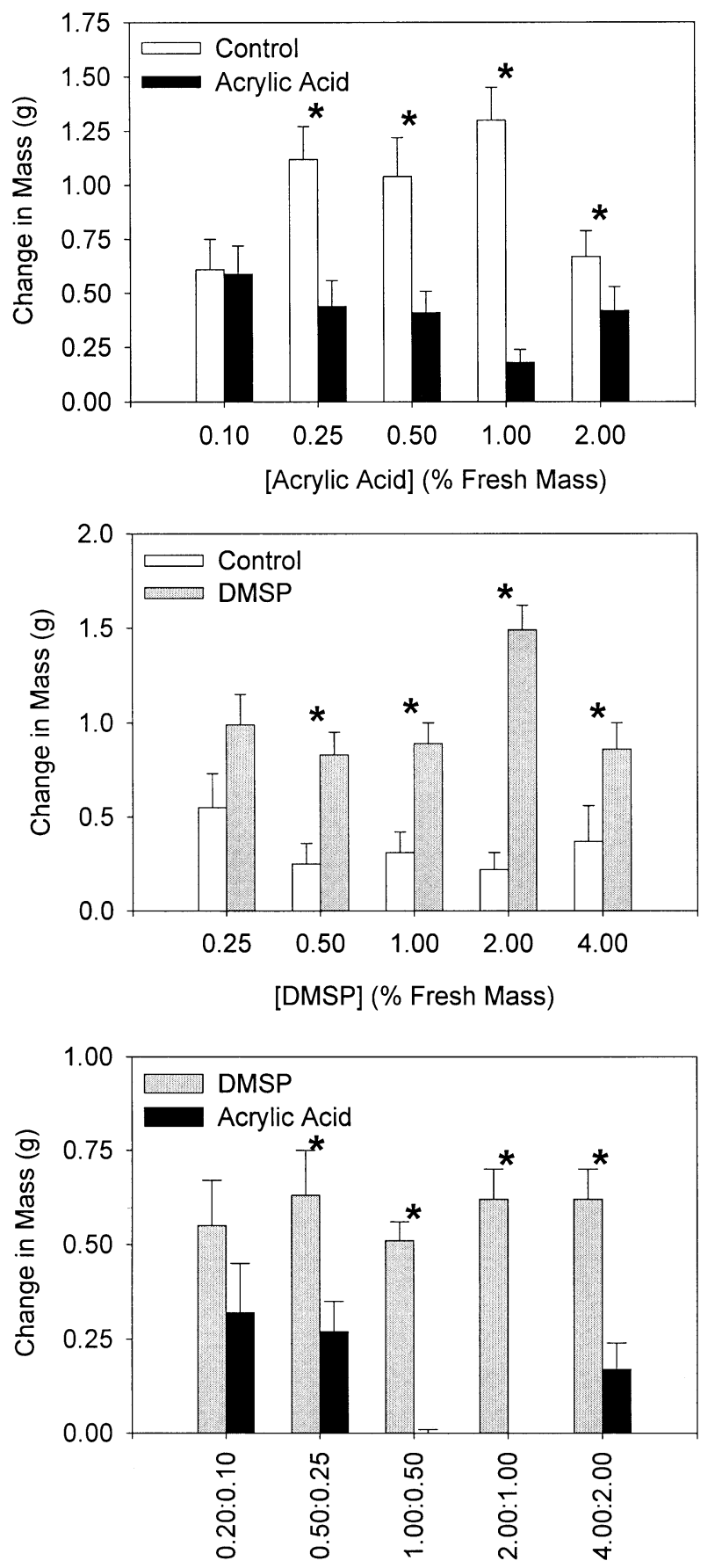

[DMSP]:[Acrylic Acid] (\% Fresh Mass)
Fig. 3. Strongylocentrotus purpuratus. Results of feeding bioassays. Urchins were offered choices of 2 of the following diets in laboratory feeding experiments: control diets, diets containing acrylic acid, or diets containing DMSP. Concentrations of compounds added to diets are given below each set of bars. Data are means $\pm 1 \mathrm{SE}$. Asterisks indicate experiments in which consumption rates differed significantly between treatments $(\mathrm{p}<0.05,1$-sample $t$-test)

\section{Strongylocentrotus droebachiensis}
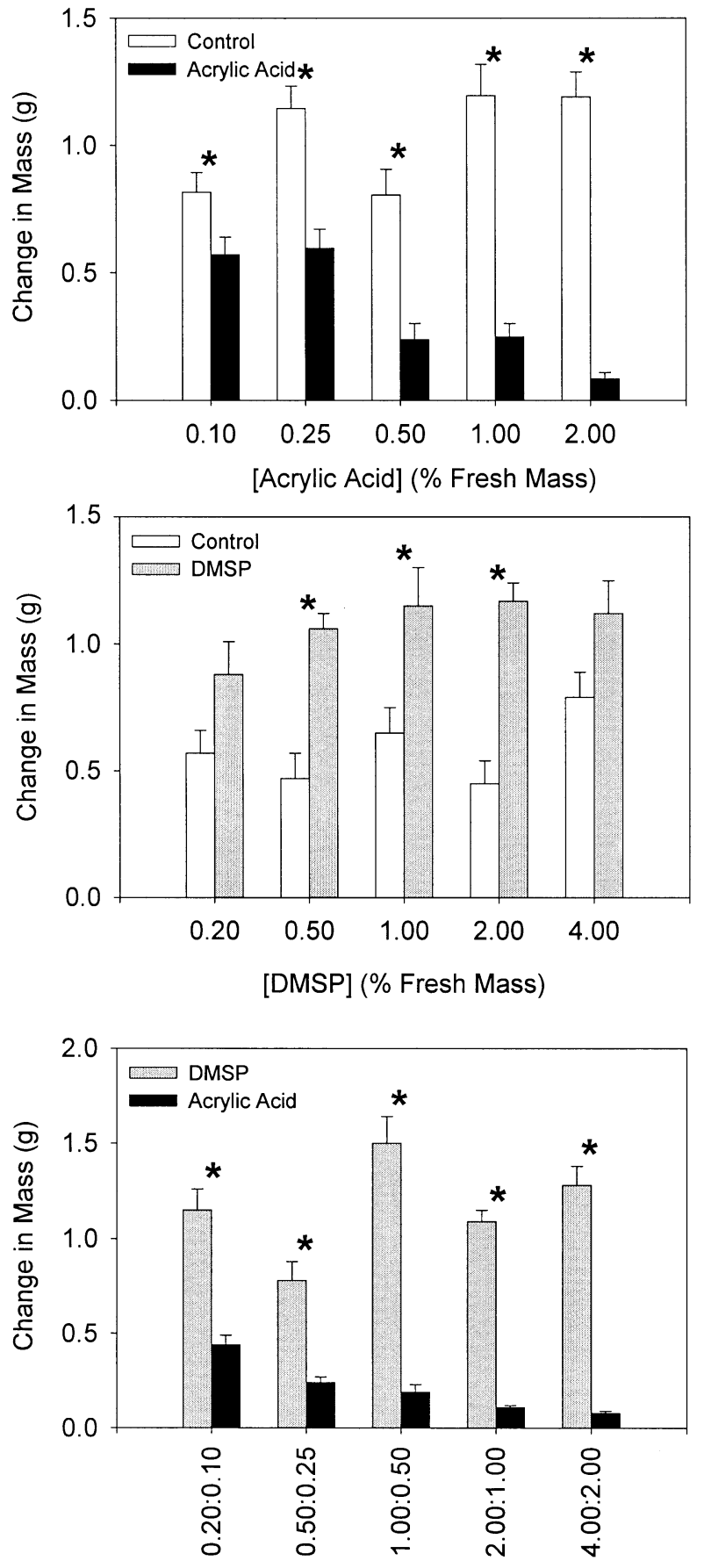

[DMSP]:[Acrylic Acid] (\% Fresh Mass)

Fig. 4. Strongylocentrotus droebachiensis. Results of feeding bioassays. Urchins were offered choices of 2 of the following diets in laboratory feeding experiments: control diets, diets containing acrylic acid, or diets containing DMSP. Concentrations of compounds added to diets are given below each set of bars. Data are means $\pm 1 \mathrm{SE}$. Asterisks indicate experiments in which consumption rates differed significantly between treatments $(\mathrm{p}<0.05,1$-sample $t$-test) 


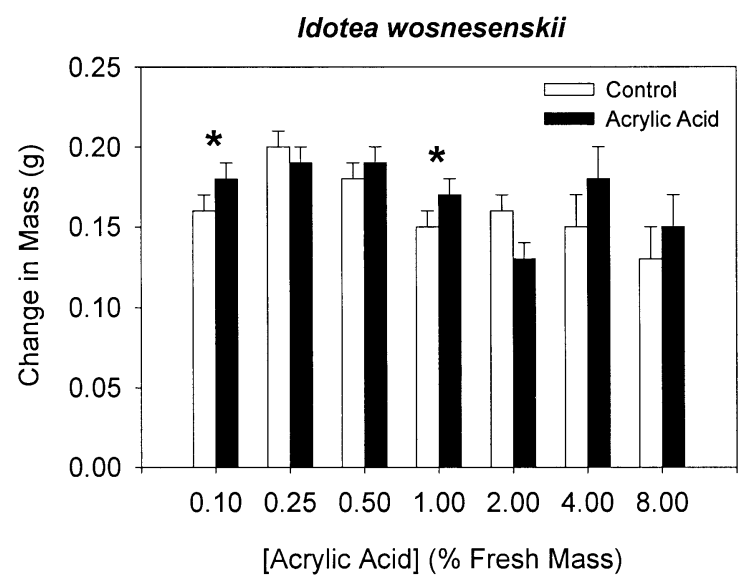

Fig. 5. Idotea wosnesenskii. Results of feeding bioassays. Isopods were offered choices of control diets or diets containing acrylic acid in laboratory feeding experiments. Concentrations of compounds added to diets are given below each set of bars. Data are means $\pm 1 \mathrm{SE}$. Asterisks indicate experiments in which consumption rates differed significantly between treatments $(\mathrm{p}<0.05,1$-sample $t$-test $)$

ate macroalgae (White 1982, Reed 1983a, Karsten et al. 1990). Concentrations of DMSP in Enteromorpha linza and Ulva californica reached $125 \mathrm{mmol} \mathrm{kg}^{-1} \mathrm{FM}$ or $1.8 \%$ FM (Table 1), while other species and Polysiphonia hendryi had somewhat lower levels. Several of the species with detectable levels of DMSP, including $E$. linza, U. fenestrata, and P. hendryi, are low-preference foods for green sea urchins (Van Alstyne unpubl. data). The algae containing high levels of DMSP are not known to contain other types of chemical defenses. Many of them had thin, delicate tissues, suggesting that physical defenses were not a cause of the low feeding preferences. Many of the species producing DMSP are fast-growing ephemeral species, similar to some of the glucosinolate-producing crucifers that produce activated defenses (Louda \& Mole 1991).

Extracts of the DMSP-containing species Ulva fenestrata and Polysiphonia hendryi also contained highly active DMSP lyase (Table 2), with DMSP cleavage rates approaching $300 \mathrm{mmol} \mathrm{\textrm {kg } ^ { - 1 } \mathrm { FM } \mathrm { min }}{ }^{-1}$. These rates were probably underestimates: we only measured soluble DMSP lyase activity, although most algal DMSP lyase enzymes appear to be at least partially membrane-bound (Steinke et al. 1998); we did not optimize the assay for salt, $\mathrm{pH}$, or other chemical requirements (Steinke et al. 1996, 1998); and we used only $10 \mathrm{mM}$ DMSP in our assays, while internal pools may reach $100 \mathrm{mM}$ or more.

Our DMSP lyase measurements and tissue-crushing experiments provide indirect evidence that herbivore grazing may cause damage to the tissues that could result in the rapid conversion of DMSP to DMS and acrylate or acrylic acid. When Ulva californica or Polysiphonia hendryi tissues were crushed, DMSP tissue concentrations decreased (Table 2). We also noted a strong odor of DMS when $P$. hendryi was crushed. Macroalgal DMSP lyase enzymes are probably active at both physiological (acid) or seawater (neutral/alkaline) $\mathrm{pH}$. Although we found an acid $\mathrm{pH}$ optimum for DMSP lyase in crude extracts of $U$. fenestrata, de Souza et al. (1996) found a pH optimum of 8 in a partially purified DMSP lyase in $U$. curvata. Cleavage of

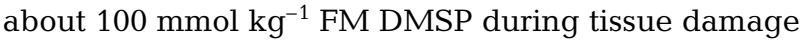
by feeding could therefore potentially occur at 300 mmol DMS kg ${ }^{-1} \mathrm{FM} \mathrm{min}^{-1}$, producing local acrylic acid concentrations of up to $0.9 \%$ FM in tens of seconds or less. We found that such concentrations were highly effective feeding deterrents to Strongylocentrotus spp. Acrylic acid was effective against $S$. droebachiensis at concentrations as low as $0.1 \%$ FM (Fig. 4), and against S. purpuratus at concentrations of $0.25 \%$ FM (Fig. 3). Therefore, although further work is needed to determine whether the physical damage resulting from herbivore grazing is sufficient to cause the cleavage of DMSP, it seems likely that DMSP cleavage may occur during grazing injury, and the resultant production of concentrated acrylic acid may act as a feeding deterrent against at least some herbivores. Our data provides the strongest evidence yet that DMSP can function as a substrate for an activated defense system in marine algae.

\section{Acrylic acid as the active ingredient}

The very high internal concentrations of DMSP in algae, combined with high potential DMSP lyase activity, present a mechanism for generating localized, concentrated acrylic acid, which is bioactive (Sieburth 1960) and may affect gut microbes in large herbivores and higher-order predators (Sieburth 1961). Both DMSP and acrylic acid are highly water-soluble, and above $\mathrm{pH} 4.4$, acrylic acid is largely deprotonated to acrylate. If these compounds become diluted in seawater, diluted acrylate at low (micromolar) concentrations is noninhibitory and a good bacterial substrate (Slezak et al. 1994). Therefore, the key to the deterrence hypothesis is that concentrated acrylic acid or acrylate is produced locally at the site of tissue injury. Acrylic acid is not very toxic (Rydzynski 1997); rather, its deterrent properties may be due to reactivity, acidity, or unpleasant taste, features common to other concentrated, volatile organic acids such as formic acid, widely used for defense among insects (Bennett et al. 1996, Rossini et al. 1997).

Acidity is also used by other macroalgae for defense, such as the sulfuric acid producer Desmarestia munda (Pelletreau 1999). However, we believe that acidity 
alone is not the mechanism responsible, since the DMSP-Cl used in the bioassays is also highly acidic, yet this compound was in contrast a feeding attractant at concentrations of 0.5 to $4 \%$ FM for Strongylocentrotus purpuratus (Fig. 3) and at 0.5 to $2.0 \%$ FM for $S$. droebachiensis (Fig. 4). Other studies have also found positive chemosensory responses to DMSP-Cl by bacteria (Zimmer-Faust et al. 1996), protozoa (Hauser et al. 1975), and fishes (Nakajima et al. 1990), although sub-micromolar concentrations may inhibit feeding by some protozoa (S. Strom pers. comm.).

Although 2 species of sea urchins were deterred by the presence of acrylic acid in our laboratory bioassays, the addition of acrylic acid to foods had no impact on feeding by the isopod Idotea wosnesenskii, even at concentrations that were 4 to 8 times greater than the maximum amount that would be found in most macroalgae (Fig. 5). It is not unusual for algal secondary metabolites to have different effects on different herbivores (Hay et al. 1987, 1988a,b, Paul et al. 1987). Mesograzers, herbivores that have limited mobility and are very small relative to the plants they consume, have been hypothesized to be mostly unaffected by their host plants' defenses, whereas larger grazers are expected to be more susceptible to the effects of these compounds (Hay et al. 1989, 1990a,b, Duffy \& Hay 1994). Many tropical species of mesograzers have been shown to be unaffected by compounds that are deterrent towards larger, more mobile grazers such as fishes and urchins. Although I. wosnesenskii is larger, more mobile, and more of a generalist than many of the mesograzer species previously studied, it is smaller than many generalist herbivores such as urchins and fishes, which are typically strongly deterred by algal secondary metabolites. It is also possible that differences in feeding mechanisms among herbivores may alter the conversion of DMSP to acrylic acid: the amount of mechanical grinding, or the presence of enzymes which might denature or inactivate DMSP lyase.

\section{Activated chemical defense systems in tropical and temperate macroalgae}

The DMSP-activated defense system shares some similarities to the activated production of halimedatrial in the tropical Pacific green algae Halimeda spp. (Paul \& Van Alstyne 1992), in which a less potent diterpenoid metabolite, halimedatetraacetate, is rapidly converted to a more potent feeding deterrent, halimedatrial, when tissues are crushed. In both systems, the conversion from the precursor to the product happens extremely rapidly, usually on the scale of seconds, and the products of the reaction are significantly more deterrent towards grazers than the compounds stored in the algae. However, in the temperate system the precursor is a feeding attractant, while in the tropical system the precursor is also a feeding deterrent, but a less effective one than the product halimedatrial.

One advantage of producing an herbivore-activated defense system is that molecules that are biologically active, presumably towards both the alga and grazers, need not be stored in the algal thallus. In activated defense systems, the precursor molecules and the enzymes are likely to be compartmentalized (Paul \& Van Alstyne 1992). The precursors and enzymes would only react upon physical damage to the tissue such as crushing or maceration by grazers. In an activated defense system, the active product is only produced in tissues that are removed by grazers; the living tissue left behind by the grazer is unaffected. Such tactics are also widely used by terrestrial vascular plants employing glucosinolate hydrolysis (Grob \& Matile 1979, Lüthy \& Matile 1984, Chew 1988, Louda \& Mole 1991, Newman et al. 1992) or cyanogenesis (Poulton 1990, Wajant et al. 1994).

Because activated defenses allow algae to produce a highly bioactive product very rapidly while avoiding autotoxicity, they have clear advantages in tropical systems, where the grazers are typically large, rapidlymoving, visually foraging fishes that travel in schools. The advantages of activated defenses are less obvious in cold-water temperate systems, where the grazers are more likely to be slow-moving sea urchins, molluscs, or arthropods that are not visual foragers. Visual foragers would quickly learn to avoid algae containing activated defenses once they discovered the algae were distaste$\mathrm{ful}_{;}$non-visual foragers would presumably have to sample an alga each time it encountered it to determine if the alga was a distasteful food unless the grazer was capable of determining the quality of the food from surface characteristics of the alga. The behavioral mechanisms by which temperate grazers chose their food in the field are not well known. Littorinid snails climb up on algae to forage during low tide and return to the substrate before the tide comes in (Van Alstyne 1988). Snails tend to leave lower-preference foods more rapidly than they leave higher-preference foods. Consuming a small portion of an alga with an activated defense may provide a grazer with a signal to move off the alga in search of a better quality food.

The main DMSP-containing macroalgal genera Enteromorpha, Ulva, and Polysiphonia are opportunistic species of the temperate eulittoral or upper sublittoral zones. They can tolerate desiccation and wide ranges of salinity, and rapidly colonize disturbed areas. Nutrification of coasts in northern Europe is leading to 'green tides' of Enteromorpha and Ulva, which are becoming major nuisances (Fletcher et al. 1990, Valeila et al. 1997). These foliose taxa are minimally protected phys- 
ically against grazers, and tropical species are sometimes used as control (preferred) foods in feeding studies (e.g., Paul \& Van Alstyne 1987, 1988, Van Alstyne \& Paul 1990), under the assumption they are not chemically defended. Our results suggest that some of the green macroalgae may in fact possess activated chemical defenses against at least some herbivores, which may possibly contribute to their widespread success.

However, deterrence ability due to DMSP cleavage probably varies geographically, and even within a population. DMSP concentrations in tropical genera are typically low, ranging from 0.5 to $1.4 \mathrm{mmol} \mathrm{kg}^{-1} \mathrm{FM}$ (Dacey et al. 1994, Karsten et al. 1994), a trend which parallels levels of brown algal phlorotannins, typically found in higher concentrations in temperate Pacific than tropical Pacific macroalgae (Steinberg 1986, Van Alstyne \& Paul 1990). In tropical fishes, acrylic acid appeared not to affect gut bacteria (Dacey et al. 1994). There is also great variation in DMSP lyase activity among algae that contain high concentrations of DMSP, even within a species (Steinke et al. 1996). Little is known about the genetics and biosynthesis of DMSP and DMSP lyase. In Trifolium repens, the genes for the cyanogenic precursors and the $\beta$-glucosidase system reside on different alleles (Nass 1972), and polymorphisms in both alleles lead to differing defense abilities (Compton \& Jones 1985, Hughes 1991). We hypothesize that the DMSP cleavage reaction will only function for defense when algae possess both high concentrations of DMSP and high DMSP lyase activities, and further work is clearly needed to determine the contribution of this reaction to the ecological success of macroalgae from diverse environments.

\section{Activated chemical defense systems in macroalgae and unicellular phytoplankton}

The DMSP cleavage reaction has also been hypothesized to function in deterrence in microalgae, thus presenting the unusual opportunity to compare and contrast the ecological function of a conserved chemical reaction between micro- and macroorganisms. Although DMSP occurs primarily in the green macroalgae, especially the Ulvophyceae, it is rare in unicellular Chlorophyta; rather, it is found primarily among the prymnesiophytes and dinoflagellates (Keller et al. 1989), including many notorious bloom-forming taxa (e.g., species of Emiliania, Phaeocystis and Alexandrium; Wolfe 2000).

DMSP lyase in phytoplankton appears to be constitutive, but the cleavage reaction is activated by physical stress or cell disruption (Wolfe \& Steinke 1996). Differences in DMSP lyase concentrations in unicellular algae have been used to test the function- ing of DMSP as part of a feeding deterrence system (Wolfe \& Steinke 1996, Wolfe et al. 1997). Some omnivorous protozoa (e.g., the dinoflagellate Oxyrrhis marina) eat microalgae polymorphic in the DMSP lyase enzyme, and DMS production following grazing suggests that the reaction occurs inside protozoan food vacuoles after ingestion, when the algae are degraded enzymatically. However, there is no evidence to date that these grazers suffer any harm from the reaction, although they may prefer prey with low-activity forms of the DMSP lyase enzyme. Other dinoflagellates are much more selective than $O$. marina and feed poorly or not at all on high-activity DMSP lyase prey, but it is still unclear whether this reaction plays a role in food selection (S. Strom \& G. Wolfe unpubl. data).

Obviously, the sacrifice of tissue by a macrophyte to deliver a deterrent signal may be a successful strategy to prevent loss of the whole organism, while in a microbe, deterrence is more likely to be all-or-nothing. Among unicellular organisms growing asexually, the reaction may act as a 'suicide' defense which might benefit the clonal prey population. An interesting intermediate case is the colonial prymnesiophyte Phaeocystis sp., which, though unicellular, forms multicelled macroscopic colonies within a mucilaginous spherical shell. Phaeocystis sp. has very active DMSP lyase and produces DMS actively during growth (Stefels \& van Boekel 1993). The result is that colonies contain concentrated acrylate (Noordkamp et al. 1998), which may function in defense against grazers or bacteria (Liss et al. 1994).

Macroalgae have several advantages over microalgae as model organisms for examining the role of DMSP in ecological systems. The grazers are larger and bioassays can be conducted with diets that differ only in acrylic acid levels. Macroalgae can also be manipulated in the field more easily than microalgae, making it easier to study the effects of environmental change on the system in a more realistic setting. We suggest this reaction presents an opportunity to compare chemical defense across size scales and at different levels of cellular organization, a relatively unexplored area in the comparative ecology of micro- and macroorganisms (Andrews 1991).

Acknowledgements. We are grateful to J. Lubchenco and B. Menge for hosting K.L.V. during her stay at Oregon State University and providing access to the Boiler Bay field site. L. Weber of the Hatfield Marine Science Center graciously allowed us to use his laboratory and the HMSC facilities, and E. and B. Sherr provided their laboratory in Oregon for measurements of DMSP. G. McKeen and the staff at SPMC helped collect urchins. This work was funded by NSF grants IBN 9896012 and 00-90825 to K.L.V. and OCE 97-5051 to G.V.W., and NSF REU grants OCE-9424050 and OCE-9731144 to the Shannon Point Marine Center 


\section{LITERATURE CITED}

Andreae MO, Raemdonck H (1983) Dimethyl sulfide in the surface ocean and the marine atmosphere: a global view. Science 221:744-747

Andrews JH (1991) Comparative ecology of microorganisms and macroorganisms. Springer-Verlag, New York

Arnold TM, Tanner CE, Hatch WI (1995) Phenotypic variation in polyphenolic content of the tropical brown alga Lobophora variegata as a function of nitrogen availability. Mar Ecol Prog Ser 123:177-183

Bates TS, Charlson RJ Gammon RH (1987) Evidence for the climatic role of biogenic sulphur. Nature 329:319-321

Bennett ATD, Lloyd MH, Cuthill IC (1996) Ant-derived formic acid can be toxic for birds. Chemoecology 7:189-190

Bischoff B, Karsten U, Daniel C, Kuck K, Xia B, Wiencke D (1994) Preliminary assessment of $\beta$-dimethylsulfoniopropionate (DMSP) content of macroalgae from the tropical island of Hainan (People's Republic of China). Aust J Mar Freshw Res 45:1329-1336

Bywood R, Challenger F (1953) The evolution of dimethyl sulphide by Enteromorpha intestinalis. Isolation of dimethyl$\beta$-carboxyethyl sulphonium chloride from the alga. Biochem J 53:26

Cantoni GL, Anderson DG (1956) Enzymatic cleavage of dimethylpropiothetin by Polysiphonia lanosa. J Biol Chem 222:171-177

Challenger F, Simpson MI (1948) Studies on biological methylation. Part 12. A precursor of the dimethyl sulphide evolved by Polysiphonia fastigiata. Dimethyl-2-carboxyethylsulphonium hydroxide and its salts. J Chem Soc 3: 1591-1597

Charlson RJ, Lovelock JE, Andreae MO, Warren SG (1987) Oceanic phytoplankton, atmospheric sulphur, cloud albedo and climate. Nature 326:655-661

Chew FS (1988) Biological effects of glucosinolates. In: Cutler HG (ed) Biologically active natural products. American Chemical Society, Washington, p 155-181

Clausen TP, Reichardt PB, Bryant JP, Werner RA, Post K, Frisby K (1989) Chemical model for short-term induction in quaking aspen (Populus tremuloides) foliage against herbivores. J Chem Ecol 15:2335-2346

Compton SG, Jones DA (1985) An investigation of the responses of herbivores to cyanogenesis in Lotus Corniculatus L. Biol J Linn Soc 26:21-38

Conn EE (1979) Cyanide and cyanogenic glycosides. In: Rosenthal GA, Janzen DH (eds) Herbivores: their interactions with secondary plant metabolites. Academic Press, New York, p 387-412

Conn EE (1981) Cyanogenic glycosides. In: Conn EE (ed) The biochemistry of plants. Academic Press, London, p 479-500

Cronin G, Hay ME (1996a) Effect of light and nutrient availability on the growth, secondary chemistry, and resistance to herbivory of two brown seaweeds. Oikos 77:93-106

Cronin G, Hay ME (1996b) Induction of seaweed chemical defenses by amphipod grazing. Ecology 77:2287-2301

Cronin G, Hay ME (1996c) Susceptibility to herbivores depends on recent history of both the plant and animal. Ecology 77:1531-1543

Dacey JWH, Wakeham SG (1986) Oceanic dimethylsulfide: production during zooplankton grazing on phytoplankton. Science 233:1314-1316

Dacey JWH, King GM, Lobel PS (1994) Herbivory by reef fishes and the production of dimethylsulfide and acrylic acid. Mar Ecol Prog Ser 112:67-74

Daly KL, DiTullio GR (1993) Biogenic production of dimethyl sulfide: krill grazing. Antarct J US 28:141-142

de Souza MP, Chen YP, Yoch DC (1996) Dimethylsulfoniopropionate lyase from the macroalga Ulva curvata: purification and characterization of the enzyme. Planta 199: 433-438

Dickson DM, Kirst GO (1986) The role of $\beta$-dimethylsulphoniopropionate, glycine betaine and homarine in the osmoacclimation of Platymonas subcordiformis. Planta 167: 536-543

Duffy JE, Hay ME (1994) Herbivore resistance to seaweed chemical defense: the roles of mobility and predation risk. Ecology 75:1304-1319

Edwards DM, Reed RH, Chudeck JA, Foster R, Stewart WDP (1987) Organic solute concentration in osmoticallystressed Enteromorpha intestinalis. Mar Biol 95:583-592

Edwards DM, Reed RH, Stewart WDP (1988) Osmoacclimation in Enteromorpha intestinalis: long-term effects of osmotic stress on organic solute concentration. Mar Biol 98:467-476

Fletcher RL, Cuomo V, Palomba I (1990) The 'green tide' problem, with particular reference to the Venice Lagoon. Br Phycol J 25:87

Grob K, Matile P (1979) Vacuolar location of glucosinolates in horseradish root cells. Plant Sci Lett 14:327-335

Groene T (1995) Biogenic production and consumption of dimethylsulfide (DMS) and dimethylsulfoniopropionate (DMSP) in the marine epipelagic zone: a review. J Mar Syst 6:191-209

Haas P (1935) The liberation of methyl sulphide by seaweed. Biochem J 29:1297-1299

Hammerstrom K, Dethier MN, Duggins DO (1998) Rapid phlorotannin induction and relaxation in five Washington kelps. Mar Ecol Prog Ser 165:293-305

Hauser DCR, Levandowsky M, Hunter SH, Chunosoff L, Hollwitz JS (1975) Chemosensory responses by the heterotrophic marine dinoflagellate Crypthecodinium cohnii. Microb Ecol 1:246-254

Hay ME, Fenical W (1988) Marine plant-herbivore interactions: the ecology of chemical defense. Annu Rev Ecol Syst 19:111-145

Hay ME, Steinberg PD (1992) The chemical ecology of plantherbivore interactions in marine vs. terrestrial communities. In: Rosenthal GA, Berenbaum MR (eds) Herbivores: their interactions with secondary plant metabolites, Vol II. Evolutionary and ecological processes. Academic Press, San Diego, p 371-413

Hay ME, Fenical W, Gustafson K (1987) Chemical defense against diverse coral-reef herbivores. Ecology 68: 1581-1591

Hay ME, Duffy JE, Fenical W, Gustafson K (1988a) Chemical defense in the seaweed Dictyopteris delicatula: differential effects against reef fishes and amphipods. Mar Ecol Prog Ser 48:185-192

Hay ME, Renaud PE, Fenical W (1988b) Large mobile versus small sedentary herbivores and their resistance to seaweed chemical defenses. Oecologia 75:246-252

Hay ME, Pawlik JR, Duffy JE, Fenical W (1989) Seaweed-herbivore-predator interactions: host-plant specialization reduces predation on small herbivores. Oecologia 75: 246-252

Hay ME, Duffy JE, Paul VJ, Renaud PE, Fenical W (1990a) Specialist herbivores reduce their susceptibility to predation by feeding on the chemically defended seaweed Avrainvillea longicaulis. Limnol Oceanogr 35:1734-1743

Hay ME, Duffy JE, Pfister CA, Fenical W (1990b) Chemical defense against different marine herbivores: are amphipods insect equivalents? Ecology 68:1567-1580 
Hughes MA (1991) The cyanogenic polymorphism in Trifolium repens L. (white clover). Heredity 66:105-115

Ilvessalo H, Tuomi J (1987) Nutrient availability and accumulation of phenolic compounds in the brown alga Fucus vesiculosus. Mar Biol 101:115-119

Karsten U, Wiencke C, Kirst GO (1990) The $\beta$-dimethylsulfoniopropionate (DMSP) content of macroalgae from Antarctica and southern Chile. Bot Mar 33:143-146

Karsten U, Wiencke C, Kirst GO (1992) Dimethylsulfoniopropionate (DMSP) accumulation in green macroalgae from polar to temperate regions: interactive effects of light versus salinity and light versus temperature. Polar Biol 12:603-607

Karsten U, Kück K, Daniel C, Wiencke C, Kirst GO (1994) A method for complete determination of dimethylsulphionoproprionate (DMSP) in marine macroalgae from different geographic regions. Phycologia 33:171-176

Keller MD, Bellows WK, Guillard RRL (1989) Dimethyl sulfide production in marine phytoplankton In: Saltzman ES, Cooper WJ (eds) Biogenic sulfur in the environment. American Chemical Society, Washington, p 167-183

Kirst GO (1989) Salinity tolerance of eucaryotic marine algae. Annu Rev Plant Physiol Plant Mol Biol 40:21-53

Kirst GO, Thiel C, Wolff H, Nothnagel J, Wanzek M, Ulmke R (1991) Dimethylsulfoniopropionate (DMSP) in ice-algae and its possible biological role. Mar Chem 35:381-388

Liss PS, Malin G, Turner SM, Holligan PM (1994) Dimethyl sulphide and Phaeocystis: a review. J Mar Syst 5:41-53

Louda S, Mole S (1991) Glucosinolates: chemistry and ecology. In: Rosenthal GA, Berenbaum MR (eds) Herbivores: their interactions with secondary plant metabolites. Academic Press, San Diego, p 123-164

Lovelock JE, Maggs RJ, Rasmussen RA (1972) Atmospheric dimethyl sulfide and the natural sulfur cycle. Nature 237 : $452-453$

Lüthy B, Matile P (1984) The mustard oil bomb: rectified analysis of the subcellular organization of the myrosinase system. Biochem Physiol Pflanz 179:5-12

Malin G, Kirst GO (1997) Algal production of dimethyl sulfide and its atmospheric role. J Phycol 33:889-896

Nakajima K, Uchida A, Ishida Y (1990) Effect of a feeding attractant, dimethyl- $\beta$-propiothetin, on growth of marine fish. Bull Jpn Soc Sci Fish 56:1151-1154

Nass HG (1972) Cyanogenesis: its inheritance in Sorghum bicolor, Sorghum sudanense, Lotus, and Trifolium repens - a review. Crop Sci 12:503-506

Newman RM, Hanscom Z, Kerfoot WC (1992) The watercress glucosinolate-myrosinase system: a feeding deterrent to caddisflies, snails and amphipods. Oecologia 92:1-7

Noordkamp DJB, Schotten M, Gieskes WWC, Forney LJ, Gottschal JC, van Rijssel M (1998) High acrylate concentrations in the mucus of Phaeocystis globosa colonies. Aquat Microb Ecol 16:45-52

Otte ML, Morris JT (1994) Dimethylsulfoniopropionate (DMSP) in Spartina alterniflora Loisek. Aquat Bot 48: 239-259

Paul VJ (1992) Ecological roles of marine natural products. Cornell University Press, Ithaca

Paul VJ, Van Alstyne KL (1987) Chemical defense and chemical variation in some tropical Pacific species of Halimeda (Halimedaceae; Chlorophyta). Coral Reefs 6:263-269

Paul VJ, Van Alstyne KL (1988) The use of ingested algal diterpenoids by Elysia halimedae MacNae (Opisthobranchia: Ascoglossa) as antipredator defenses. J Exp Mar Biol Ecol 119:15-29

Paul VJ, Van Alstyne KL (1992) Activation of chemical defenses in the tropical green algae Halimeda spp. J Exp Mar Biol Ecol 160:191-203
Paul VJ, Hay ME, Duffy JE, Fenical W, Gustafson K (1987) Chemical defense in the seaweed Ochtodes secundiramea (Montagne) Howe (Rhodophyta). Effects of its monoterpenoid components upon diverse coral-reef herbivores. J Exp Mar Biol Ecol 114:249-260

Pavia H, Cervin G, Lindgren A, Aberg P (1997) Effects of UV$B$ radiation and simulated herbivory on phlorotannins in the brown alga Ascophyllum nodosum. Mar Ecol Prog Ser 157:139-146

Peckol P, Krane JM, Yates JL (1996) Interactive effects of inducible defense and resource availability on phlorotannins in the North Atlantic brown alga Fucus vesiculosus. Mar Ecol Prog Ser 138:209-217

Pedersen A (1984) Studies on phenol content and heavy metal uptake in fucoids. Hydrobiologia 116/117:498-504

Pelletreau KN (1999) The role of sulfuric acid in the brown alga Desmarestia munda. MSc thesis, Western Washington University, Bellingham

Peterson CH, Renaud PE (1989) Analysis of feeding preference experiments. Oecologia 80:82-86

Poulton JE (1990) Cyanogenesis in plants. Plant Physiol 94: 401-405

Reed RH (1983a) Measurement and osmotic significance of dimethylsulphoniopropionate in marine macroalgae. Mar Biol Lett 4:173-181

Reed RH (1983b) The osmotic significance of tertiary sulphonium and quaternary ammonium compounds in marine macroalgae. Br Phycol J 18:208

Renaud PE, Hay ME, Schmitt TM (1990) Interactions of plant stress and herbivory: intraspecific variation in the susceptibility of a palatable versus an unpalatable seaweed to sea urchin grazing. Oecologia 82:217-226

Rhodes D, Hanson AD (1993) Quaternary ammonium and tertiary sulfonium compounds in higher plants. Annu Rev Plant Physiol Plant Mol Biol 44:357-384

Rossini C, Attygalle AB, González A, Smedley SR, Eisner M, Meinwald J, Eisner T (1997) Defensive production of formic acid ( $80 \%$ ) by a carabid beetle (Galerita lecontei). Proc Natl Acad Sci USA 94:6792-6797

Rydzynski K (1997) Acrylic acid. World Health Organization, Geneva

Seigler DS (1991) Cyanide and cyanogenic glycosides. In: Rosenthal GA, Berenbaum MR (eds) Herbivores: their interactions with secondary plant metabolites. Academic Press, San Diego, p 35-78

Sieburth JM (1960) Acrylic acid, an 'antibiotic' principle in Phaeocystis blooms in Antarctic waters. Science 132: 676-677

Sieburth JM (1961) Antibiotic properties of acrylic acid, a factor in the gastrointestinal antibiosis of polar marine animals. J Bacteriol 82:72-79

Slezak DM, Puskaric S, Herndl GJ (1994) Potential role of acrylic acid in bacterioplankton communities in the sea. Mar Ecol Prog Ser 105:191-197

Stefels J, van Boekel WHM (1993) Production of DMS from dissolved DMSP in axenic cultures of the marine phytoplankton species Phaeocystis sp. Mar Ecol Prog Ser 97: 11-18

Steinberg PD (1986) Chemical defenses and the susceptibility of tropical brown algae to herbivores. Oecologia 69: $628-630$

Steinke M, Daniel C, Kirst GO (1996) DMSP lyase in marine macro- and microalgae: intraspecific differences in cleavage activity. In: Kiene RP, Visscher P, Kirst G, Keller M (eds) Biological and environmental chemistry of DMSP and related sulfonium compounds. Plenum Press, New York, p 317-324 
Steinke M, Wolfe GV, Kirst GO (1998) Partial characterization of dimethylsulfoniopropionate (DMSP) lyase in 6 strains of Emiliania huxleyi. Mar Ecol Prog Ser 175:215-225

Sterner O (1985) The Russelaceae sesquiterpenoids. PhD dissertation, Lund University, Lund

Sterner O, Bergman R, Kihlberg J, Wickberg B (1985) The sesquiterpenes of Lactarius vellereus and their role in a proposed chemical defense system. J Nat Prod 48:279-288

Targett NM, Arnold TM (1998) Predicting the effects of brown algal phlorotannins on marine herbivores in tropical and temperate oceans. J Phycol 34:195-205

Valeila I, McClelland J, Hauxwell J, Behr PJ, Hersh D, Foreman K (1997) Macroalgal blooms in shallow estuaries: controls and ecophysiological and ecosystem consequences. Limnol Oceanogr 42:1105-1118

Van Alstyne KL (1988) Herbivore grazing increases polyphenolic defenses in the intertidal brown alga Fucus distichus. Ecology 69:655-663

Van Alstyne KL, Paul VJ (1989) The role of secondary metabolites in marine ecological interactions. Proc 6th Int Coral Reef Symp 1:175-186

Van Alstyne KL, Paul VJ (1990) The biogeography of polyphenolic compounds in marine macroalgae:temperate brown algal defenses deter feeding by tropical herbivorous fishes. Oecologia 84:158-163

Editorial responsibility: Charles Birkeland (Contributing Editor), Honolulu, Hawaii, USA
Wajant H, Riedel D, Benz S, Mundry KW (1994) Immunological localization of hydroxynitrile lyases from Sorghum bicolor L. and Linum usitatissimum L. Plant Sci 103: 145-154

White RH (1982) Analysis of dimethyl sulfonium compounds in marine algae. J Mar Res 40:529-536

Wolfe GV (2000) The chemical defense ecology of marine unicellular plankton: constraints, mechanisms, and impacts. Biol Bull 198:225-244

Wolfe GV, Steinke M (1996) Grazing-activated production of dimethyl sulfide (DMS) by two clones of Emiliania huxleyi. Limnol Oceanogr 41:1151-1160

Wolfe GV, Sherr EB, Sherr BF (1994) Release and consumption of DMSP from Emiliana huxleyi during grazing by Oxyrrhis marina. Mar Ecol Prog Ser 111:111-119

Wolfe GV, Steinke M, Kirst GO (1997) Grazing-activated chemical defense in a unicellular marine alga. Nature 387 : 894-897

Yates JL, Peckol P (1993) Effects of nutrient availability and herbivory on polyphenolics in the seaweed Fucus vesiculosus. Ecology 74:1757-1766

Zimmer-Faust RK, de Souza MP, Yoch DC (1996) Bacterial chemotaxis and its potential role in marine dimethylsulfide production and biogeochemical sulfur cycling. Limnol Oceanogr 41:1330-1334

Submitted: December 30, 1999; Accepted: August 31, 2000 Proofs received from author(s): March 5, 2001 